\title{
Impact of Service Quality Dimension on Customer Satisfaction of Domestic Electricity Consumers in Sri Lanka
}

\author{
U.S.Samaraweera ${ }^{1} \&$ R.A Rathnasiri ${ }^{2}$ \\ ${ }^{1}$ Ceylon Electricity Board, \\ SRI LANKA \\ ${ }^{2}$ Department of Banking and Finance, Faculty of Business Studies \& Finance, \\ Wayamba University of Sri Lanka \\ Kuliyapitiya \\ SRI LANKA \\ udarasulakshana@gmail.com ${ }^{1}, \underline{\text { rathnasiri@wyb.ac.lk }}{ }^{2}$
}

\begin{abstract}
Electricity is becoming an essential part of life considering the increasing needs and wants of human beings. In Sri Lanka, Electricity is widely used for domestic purposes by Domestic Consumers. Customers are always expected to get the new connections within a short period of time, un-interrupted service at any time, affordable tariff system, easy payment facilities and customer-oriented attitudes of employees etc. Evidences do not prove that Ceylon Electricity Board (CEB) has been able to meet the above customer expectations fully. The problem was the gap between expected service and perceived service delivered to domestic electricity consumers by CEB. In some extent CEB is lacking behind of understanding about the customer expectations and thereby encountering difficulties in transforming customer expectations in to superior service quality specifications that employees can understand and execute. This study is an effort to come up with the solution to the major research problem that was identified by the authors as service quality identification through customer satisfaction. Current study desires to develop an empirical model of service quality in terms of electricity services that may form a basis for a better understanding of its determinants. Specifically, this study aims to identify the dimensions of service quality of electricity services provided by the Ceylon Electricity Board in North Western Province. Accordingly, scope of the present research is confined to service marketing concept: customer satisfaction. Customers are not only buying the product or arriving at the organization but including industry owners outside agencies, other outside personnel who are beneficiaries in the service offered by CEB. This study is based on the domestic electricity consumers in North Western Province in Sri Lanka. The North western province is divided in to seven areas. These seven areas are subdivided into twenty five consumer service centers. There were 863,581 consumers at the end of 2016.Using Johnson \& Kuby (2007) simple sampling technique, sample size was found as 300 . Therefore, 300 respondents were selected for 25 consumer service centers proportionate to the population of each consumer service center. Data were collected using a questionnaire, from 300 respondents. Customer satisfaction is measured with service quality dimensions of tangibility, empathy, responsiveness, reliability, assurance. Correlation analysis and multiple regression analysis were used
\end{abstract}


to analyze the data. The model framework developed based on the SERVQUAL model invented by Parasuraman, Zeithamal and Berry (1988). The results showed that tangibility, empathy, responsiveness, reliability and assurance had significant positive relationships on customer satisfaction. Based on the findings some suggestions for electricity utility were discussed. Findings will be useful to CEB for enhancing its effectiveness and to build up the high level of customer satisfaction. Moreover, findings of the study enrich the empirical literature and provide important messages for the policy makers and enlightening substantial scope for future research.

Keywords: Ceylon Electricity Board, Customer Satisfaction, Electricity Services, Service Quality.

\section{INTRODUCTION}

Consumer satisfaction is a key aspect in ensuring the continuity of liberalization and privatization policies set up during the last decades in the public service sector. Citizens' support to public policies must be ensured since after all, citizens are the end users. During the past few years, low satisfaction of citizens towards public services have made policy makers to consider changes in the way the public services are provided, including some relevant changes (Akinboade et al., 2012).

In Sri Lankan context, the Ceylon Electricity Board is a government sector monopoly organization. Especially, in the South Asian Region, Sri Lanka has been ranked the best one in terms of electrification rate according to the Central Bank Report (2013). Meanwhile, as a whole, public sector organizations have been stressed to deliver quality services and improve efficiencies (Randall, 2004). In addition, Since Sri Lanka gained independence in 1948, the public sector has undergone a number of transformations. The public sector is

under increasing pressure to demonstrate that their services are customer-focused and that continuous performance improvement is being delivered. Importantly, In the Asian region, China and India have already achieved 8 percent of growth level (Gowan et al., 2001). The recorded average growth rate for the period 1977-2018 was 5.6 per cent in Sri Lanka (CBSL, 2018). Thus, with the expansion of economic activities, there will be greater demand for electricity or power generation in the country. This will signal out for more customer oriented quality service for the customers.

Generally, electricity power supply for the domestic and industrial sector took a vital role in economic development. In nutshell, electricity services are recognized as the live blood to the nation and its development. Further, it provides the power or energy to other industries to do the functions properly and perfectly. If there is a problem in terms of power supply, the whole economy will be in danger. Due to that, the government should focus on electricity services as a prominent and fundamental one.

Furthermore, in third world countries, many cases of violations of the rights, such as incorrect calculation of bills (increasing penalties, calculation on power capability, etc.) are reported. 
An unreasonable restriction of power supply, is not adequately addressed by the electricity consumers (Balakrishnan et al., 1999).

Ceylon Electricity Board (CEB) is the largest electricity supplier in Sri Lanka, a body corporate established under the Parliament Act No.17 of 1969. With a market share of nearly 100 percent and it controls all major functions of generation, transmission and distribution of electricity energy to reach all categories of consumers nationwide. It is one of the only two on-grid electricity companies in the country; the other being Lanka Electricity Company. CEB earned approximately LKR 188 billion in 2016 with a total of nearly 5.64 million consumer accounts (www.ceb.lk).

Ceylon Electricity Board (CEB) manages all its business activities in such a manner which cares for the natural and manmade environment and contributes to sustainable development. By means of openness in dealing with environmental issues, they intend to create confidence in their activities on the part of the public, customers, authorities, employees and owners. Ceylon Electricity Board actively pursues a policy of incorporating and integrating environmental considerations into their activities. CEB have planned to develop and maintain an efficient, coordinated and economical system of electricity supply to Sri Lanka, while adhering core values of quality, efficiency and effectiveness, commitment, safety, professionalism and sustainability.
When analyzing the load curve of the daily electricity consumption in Sri Lanka, it is obvious that most of the electricity consumers are domestic users. However, when considering the developed countries in the world, electricity consumption is highly used for industrial purposes. Therefore, those countries get an economic benefit by utilizing electricity. Accordingly, the use of electricity for most developed countries is profitable. However, CEB presently faces a nonprofitable situation but it serves the nation.

Electricity is becoming an essential part of life considering the increasing needs and wants of human beings. In Sri Lanka, Electricity is widely used for domestic purposes by Domestic Consumers. Because, Sri Lanka is now just above the level of a developing country and yet, electricity consumption for industrial purposes is relatively low. The main problem facing CEB is most of its consumers are found not to be satisfied with the services provided by CEB.

Table 1. Consumer complaints in North-Western Province

\begin{tabular}{|cc|}
\hline Table 1. Consumer complanits & \\
\hline Year & No of Complaints \\
\hline 2010 & 9533 \\
2011 & 10435 \\
2012 & 12118 \\
2013 & 12584 \\
2014 & 13059 \\
\hline Source: Summary of Consumer Complains 2014 & \\
\hline
\end{tabular}

Above table shows the complaints which the Ceylon Electricity Board had for their services throughout the last few years in NWP. Also the gap 
between a customer's expectation before and after service consumption affects the level of a customer's satisfaction or dissatisfaction (Clow \& Vorhies, 1993). Therefore, an attempt was made to find the Impact of the Service Quality Dimensions towards Customer Satisfaction. The questions of this research to find out relationships between each service quality dimension with customer satisfaction, How service quality dimensions effect on customer satisfaction \& find out the most influential service quality dimension which can affect for the satisfaction.

\section{LITERATURE REVIEW}

In present service quality is considered as one of the major determinants in measuring the success of any industry and majority of the marketers agree that service quality has created a significant influence on customers to differentiate the organizations which are competing and contributing towards the customer satisfaction effectively (Parasuraman et al., 1985). Asubonteng et al., (1996), has mentioned that service quality is the difference between customer expectation for service performance before they encounter the service and their perception of the received services. Service quality can be described as the delivery of excellent or superior service in relation with the customer expectation (Zeithaml et al., 1996). Some researchers have described service quality as a multidimensional construct and this is considered as a result of the comparison which customers make between the expectations and the perception of the way the services are being performed. There is a positive correlation between service quality and customer satisfaction (Khan \& Fasih, 2014). SERVQUAL Scale is one of the most accepted service quality assessment scales. It was developed by Parasuraman, et al., (2005). It is used in five categories (tangibles, reliability, assurance, empathy and responsiveness) to measure service quality.

Many researchers have given various definitions relevant to the word "Service" under different dimensions. As mentioned by (Arslan et al., 2015) in their research service quality is considered as one of the main factors which affects customer satisfaction and due to that reason, this is considered as an important factor in the Service Industry. As mentioned by them further among the variety of researches which were done in relation with service quality the researches which were done by (Zeithaml et al., 1988) are considered as the important ones. Arslan et al., (2015) further mentioned that Zeithaml, Parasuraman and Berry worked together and introduced a model to analyze the service quality named as "SERVQUAL Model". This model includes main factors such as Tangibility, Reliability, Responsiveness, Assurance and Empathy.

Eshghi, (2008) and Glaveli et al., (2006) define service quality as an overall assessment of service by the customer and they show that by defining service quality the companies are able to provide services with high quality resulting increased customer satisfaction. According to 
Parasuraman et al., (1985) and Ladhari, (2009) when understanding the service quality, it involves acknowledging the characteristics of services such as intangibility, heterogeneity and inseparability. Thus, based on their views service quality can be measured easily. Further service quality can be described as the difference between a customer's expectation for service performance before encountering the service and their idea on the services received.

In the developing world service industry is considered as the backbone of the economy and this has an important place in the economy to support various fields such as agriculture and industrial sector. In a competitive business environment delivering quality services is the key to the success of the business and long-term survival of the business. (Parasuraman et al.,1985). Personalized, quality and friendly relationships with service providers are considered the best way to enhance customer satisfaction and attract new customers and the retention of the existing customers.

\section{RESEARCH METHODOLOGY}

This study attempts to identify the link between the service quality and customer satisfaction related to $\mathrm{CEB}$ which is the main utility provider in
Sri Lanka. As per the administration purpose of CEB, North Western Province has been divided into seven areas. Namely Kurunegala, Wariyapola, Chilaw, Kuliyapitiya, Wennappwa, Puttalam and Narammala. There are approximately 863,581 Electricity consumers in the province. A sample of 300 consumers out of total consumers were selected according to the Johnson \& Kuby, (2012) sample calculator at 95 percent of confidence level. These 300 respondents were selected in 25 consumer service centers at several areas according to the consumer ratio.

Survey method is employed using a standard questionnaire, which has a set of questions as Part $1 \&$ Part 2. Part 1 , questions consist of demographic factors like age, gender, material status, education level. Part 2 consists of 26 statements, measuring the Tangibility, Reliability, Responsiveness, Assurance and Empathy. All items are measured on the likert scale and respondents are requested to indicate their choice on a 5 -point scale, ranging from strongly disagree (1) to strongly agree (5).

First normality of the distribution would be analyzed to ensure the data is normally distributed. Then descriptive statistics would be performed to ensure averages and deviations of the collected data by using mean and the standard 
deviation. Requirement of finding out reliability of the data Cronbach's alpha would be used.

The conceptual model of the study as follows.

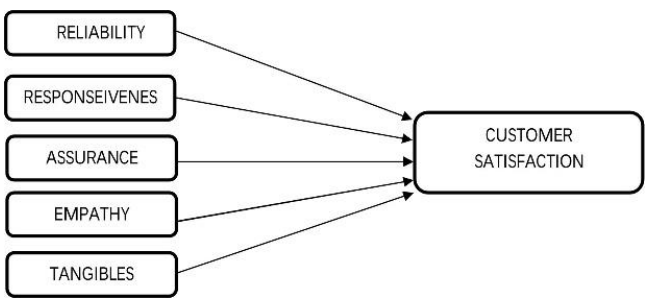

\section{Figure 1. Conceptual Framework}

As shown in Figure 1, it illustrates that tangibility, reliability, assurance, empathy, responsiveness are the five service quality dimensions that can impact customer satisfaction (Khan \& Fasih, 2014). Satisfaction, on the other hand, is more inclusive: it is influenced by perception of service quality, product quality and price as well as situational factors and personal factors. The gap between a customer's expectation before and after service consumption affects the level of a customer's satisfaction or dissatisfaction (Clow \& Vorhies, 1993). Support of the view of customers who are exposed to a service could have their expectations of service quality influenced.

Research Hypothesis can be express as below:

H1: There is a positive relationship between Tangibility and customer satisfaction.
$\mathrm{H} 2$ : There is a positive relationship between Empathy and customer satisfaction.

H3: There is a positive relationship between Responsiveness and customer satisfaction.

H4: There is a positive relationship between Reliability and customer satisfaction.

H5: There is a positive relationship between Assurance and customer satisfaction.

The analysis of data is based on the multivariable analysis which is a critical section of the research. The correlation analysis would be used to find out the relationship between different service quality dimensions and customer satisfaction. Secondly, multiple regression analysis is used to identify the impact of service quality on customer satisfaction.

\section{FINDINGS AND DISCUSSION}

This sample consists of 59 percent male (177) and 41percent female (123) respondents. Among those 7 percent are under 21 years, 23 percent are belonging to the 21-30 age group, 31 percent are belonging to the $31-40$ age group, 21percent are belonging to the $41-50$ age group $\& 18$ percent are more than 50 years old.

The summary of personnel variables, which include gender, age, marital status, educational level is recorded in Table 1. 
Table 1. Summary of Sample Profile

\begin{tabular}{|llcc|}
\hline Personal variables & & No.of Consumers & Percentage\% \\
\hline Gender & Male & 177 & $59 \%$ \\
\hline & Female & 123 & $41 \%$ \\
\hline Age & & & \\
\hline & Under 21 years & 21 & $7 \%$ \\
\hline & 21 to 30 years & 69 & $23 \%$ \\
\hline & 31 to 40 years & 93 & $31 \%$ \\
\hline & 41 to 50 years & 63 & $21 \%$ \\
\hline & Over 50 years & 54 & $18 \%$ \\
\hline Marital status & & & $21 \%$ \\
\hline & Single & 63 & $78 \%$ \\
\hline & Married & 234 & $1 \%$ \\
\hline & Other & 3 & $4 \%$ \\
\hline Educational level & Primary & 12 & $62 \%$ \\
\hline & Secondary & 186 & $16 \%$ \\
\hline & Graduate & 48 & $18 \%$ \\
\hline & Other & 54 & \\
\hline
\end{tabular}

Source: Survey Data

\subsection{Descriptive Statistical Analysis}

Since it is required to find the confidence of data mean and standard deviation has been found using SPSS. On this basis it can be decided whether views can be accepted or not. Table 2 in Appendix 1 shows the mean and Standard deviation calculated to each factor.

According to Table 2 in which all the variables are brought together, here it is obvious that for all the questions, participants have agreed, that conclusion found through the mean on each. For all the questions the mean has exceeded 2.5 which can be considered as the middle, which it exceeds 3.7 and gone up to 4.7 for all the cases. So that it is obvious that almost all the participants agreed with the relevant statements.

\subsection{Reliability of Data}

Although data has been gathered and listed down, before processing them it is required to find the validity and reliability of data. It has been done through Cronbach's Alpha using SPSS.

\section{Table 3. Statistics of Reliability Coefficient.}

\begin{tabular}{|c|c|c|}
\hline $\begin{array}{c}\text { Cronbach's } \\
\text { Alpha }\end{array}$ & $\begin{array}{c}\text { Cronbach's Alpha } \\
\text { Based on } \\
\text { Standardized } \\
\text { Items }\end{array}$ & $\begin{array}{c}\mathrm{N} \text { of } \\
\text { Items }\end{array}$ \\
\hline .912 & .911 & 26 \\
\hline
\end{tabular}

Source: Survey Data 
According to Table 3, it is obvious that alpha value, which is known as reliability coefficient has exceeded 0.9. which means that there is very high consistency within the data. (Cronbach's Alpha > 0.7) Therefore, it is obvious that views collected in the current research are valid and having very high reliability therefore those can be used to further analysis.

\subsection{Correlation Analysis}

Pearson correlation is calculated to find the association between the independent variables and dependent variable. Therefore, all dependent variable has been tested with its statements derived from the indicators (Table 4). According to the above table 4, there is Correlation between Customer satisfaction upon Tangibility, Empathy, Responsiveness, Reliability \&
Assurance and that is within 99\% confidence level. The correlation analysis revealed that all service quality dimensions have positive association with the customer satisfaction.

\subsection{Regression Analysis}

Multiple regression analysis has been performed to assess the impact of service quality on customer satisfaction. Accordingly, in the regression model customer satisfaction regressed against the tangibility, empathy, responsiveness, reliability and assurance. The outcome of the regression analysis is useful to identify significant factors in explaining customer satisfaction on electricity consumption. The table 5, 6 and 7 reflect the outcome of the regression analysis.

Table 5. Results of Regression Analysis -Model Summary

\begin{tabular}{|l|r|r|r|r|}
\hline $\begin{array}{l}\text { Mode } \\
1\end{array}$ & $\mathrm{R}$ & R Square & \multicolumn{1}{|c|}{$\begin{array}{c}\text { Adjusted R } \\
\text { Square }\end{array}$} & $\begin{array}{c}\text { Std. Error of the } \\
\text { Estimate }\end{array}$ \\
\hline 1 & $.924^{\mathrm{a}}$ & .853 & .850 & .19944 \\
\hline
\end{tabular}

a. Predictors: (Constant), Relibilit_All, E_All, T_All, Assur_All, Res_All

Table 6. Results of Regression Analysis -ANOVA Table

\begin{tabular}{|c|c|c|c|c|c|c|}
\hline \multicolumn{2}{|c|}{ Model } & $\begin{array}{l}\text { Sum of } \\
\text { Squares }\end{array}$ & $\mathrm{df}$ & $\begin{array}{c}\text { Mean } \\
\text { Square }\end{array}$ & $\mathrm{F}$ & Sig. \\
\hline 1 & Regression & 67.625 & 5 & 13.525 & $\begin{array}{r}338.12 \\
5\end{array}$ & $.000^{\mathrm{b}}$ \\
\hline & Residual & 11.615 & 294 & .040 & & \\
\hline & Total & 79.239 & 299 & & & \\
\hline
\end{tabular}

a. Dependent Variable: CS_All

b. Predictors: (Constant), Relibilit_All, E_All, T_All, Assur_All, Res_All 
According to the above table 5, Multiple regression of Customer satisfaction upon Tangibility, Empathy, Responsiveness, Reliability \& Assurance obtained using SPSS. As results; Dependent variable which is Customer satisfaction has been shown to have an R Square value of $0.853 \&$ Adjusted R Square value of 0.850 . Which means $85 \%$ of the variation in the customer satisfaction is explained by the five factors of Tangibility, Empathy, Responsiveness, Reliability \& Assurance.
According to the above table 6, ANOVA table of multiple regression of Customer satisfaction upon Tangibility, Empathy, Responsiveness, Reliability \& Assurance obtained using SPSS. According to the table $\mathrm{P}$ value is less than $0.001(\mathrm{P}<0.001)$. This proves that the overall regression model is significant.

Table 7. Results of the Regression Analysis-Coefficients

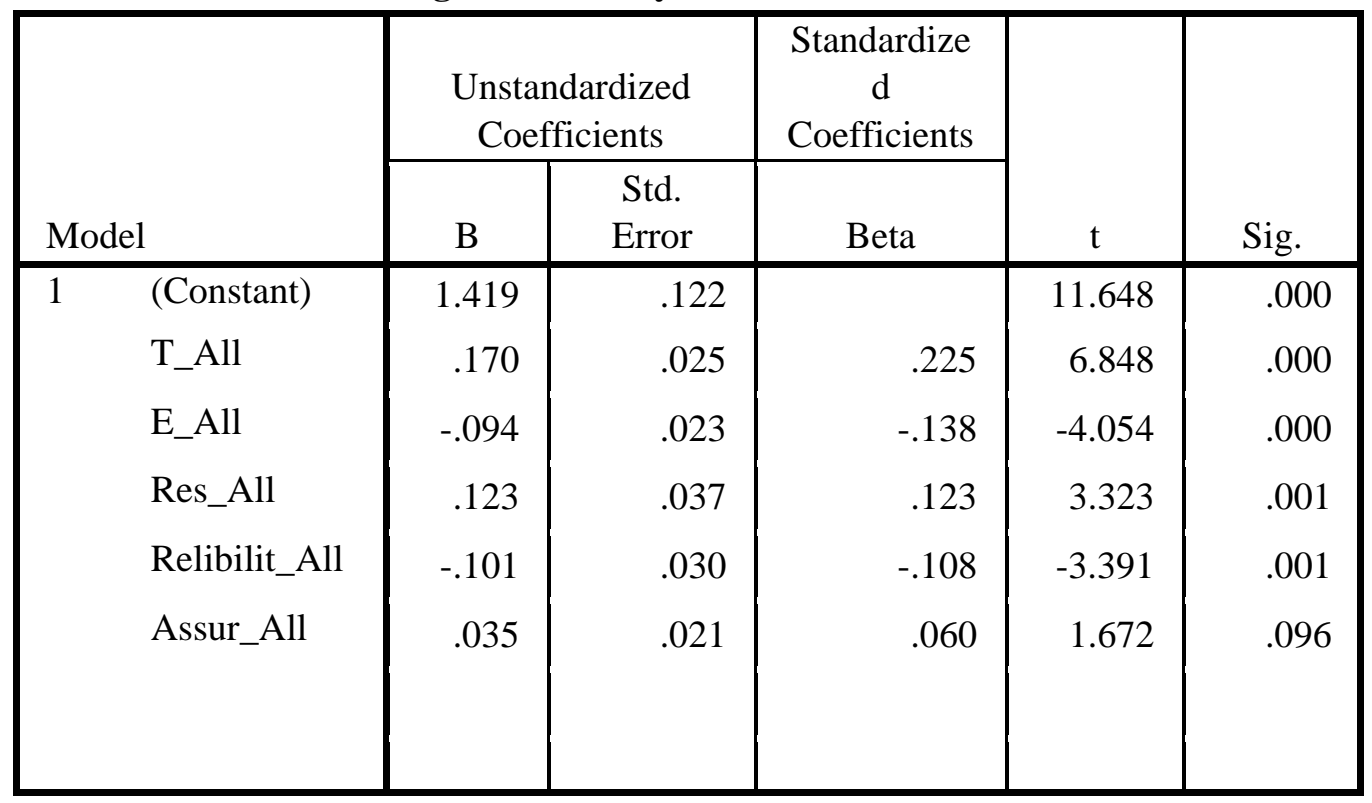

a. Dependent Variable: CS_All

Source: Author Constructed

According to the above table 7, Coefficients table of multiple regression of Customer satisfaction upon Tangibility, Empathy, Responsiveness, Reliability \& Assurance obtain using SPSS. As per the results; Tangibility, Empathy, Responsiveness, Reliability have $\mathrm{P}$ values are less than 0.05. Assurance has $\mathrm{P}$ value of less than 0.1 . Therefore, if we consider all predictors individually (Tangibility, Empathy, 
Responsiveness, Reliability and Assurance) it proves that;

- There is a positive relationship between Tangibility and customer satisfaction.

- There is a positive relationship between Empathy and customer satisfaction.

- There is a positive relationship between Responsiveness and customer satisfaction.

- There is a positive relationship between Reliability and customer satisfaction.

\section{CONCLUSION}

The research presents the results of a study carried out on Impact of service quality dimensions towards customer satisfaction of the electricity service provided by the Ceylon Electricity Board in North Western Province of Sri Lanka. Customer satisfaction is the feeling or attitude of a customer towards a product or service after it has been used. SERVQUAL instrument developed by Parasuraman, Zeithamal and Berry (1988) is used to measure customer satisfaction. SERVQUAL addresses many elements of service quality divided into the dimensions of tangibles, reliability, responsiveness, assurance, and empathy. Descriptive statistics analysis was conducted to determine the characteristics of the data set. Then test the reliability of data by Cronbach's Alpha. Then Multiple regression analysis has been performed.

Research concludes that service tangibles such as modern looking equipment, physical facilities, service performed in promised time, neat appealing of delivery personnel, the comfort at the service delivery point influenced directly and indirectly to the customer satisfaction. This means there should be well facilitated consumer service areas with $\mathrm{A} / \mathrm{C}$ facility, car parking facility, modern electronic devices to carry out one day new service etc.

Service empathy such as individual attention, convenient operation hours, consider needs of customers at the service delivery point influenced directly and indirectly to the customer satisfaction. It is useful to develop a web based system to get new service connections, change the billing method, apply for bulk supply etc.

Service responsiveness such as not spending much time in line, employees are willing to help, eliminating potential errors, quick response at the service delivery point influenced directly and indirectly to the customer satisfaction. CEB introduced electronic meters (smart meters) with remote reading facilities which can overcome the potential errors of large scale bulk supply industries. Government should facilitate CEB to introduce smart meters to all domestic consumers as well. On the other hand CEB should well train their staff to maintain good service to their consumers.

Reliability such as correctly performing the service, error free records, solving the problems influenced directly and indirectly to the customer satisfaction. Consumers are always willing to have reliable service. As an example consumers are not aware of how to get a new single phase connection, new three phase 
connection, change the account, if their electricity bill is correct or not, etc.

Service assurance such as employees should be trustworthy, feeling safe, employees consistently courteous influenced directly and indirectly to the customer satisfaction. These days $\mathrm{CEB}$ has introduced many protection systems to their switch gears and equipment. But still some people get electric shock due to lack of knowledge \& illegal tapping. CEB should educate people using the media about these bad practices. On the other hand, employees should be well trained to provide trustworthy and courteous service to the consumer. Government \& CEB should try to develop these facilities to increase the customer satisfaction.

\section{REFERENCES}

Achchuthan S., Sivathaasan N., Jayasundara J. M. R. S., (2014), "Service Quality Dimensions of Electricity Services: Evidence from Electricity Board in Sri Lanka", Asian Social Science; Vol. 10(17), Canadian Center of Science and Education, ISSN 1911-2017 E-ISSN 1911-2025

Akinboade O.A., Kinfack E.C., Mokwena M.P., (2012), “An analysis of citizen satisfaction with public service delivery in the Sedibeng district municipality of South Africa, International Journal of Social Economics, Vol.39(3), 182-199 https://doi.org/10.1108/03068291 211199350
Arslan M., Iftikhar M., Zaman R., Heilbronn H., (2015) "Effect of Service Quality Dimensions on Customer Satisfaction: A Comparative Analysis of Pakistan Telecom Sector.", University of Strathclyde.

Asubonteng P., McCleary K.J., Swan J.E., (1996), SERVQUAL revisited: a critical review of service quality, Journal of Services Marketing,Vol. 10 (6): 20.

Balakrishnan N., Kanet J.J Sridharan S.V., (1999), "Early/tardy scheduling with sequence dependent setups on uniform parallel machines", Department of Management, Clemson University, Clemson, USA.

Central Bank Annual Report, 2013. Central Bank of Sri Lanka

Central Bank Annual Report, 2018. Central Bank of Sri Lanka

Clow, K. F. \& Vorhies, D. W. (1993). Building a Competitive Advantage for Service Firms. Journal of Services Marketing, 7(1), 22-32Vol. 3(1).Eshghi A., (2008), "Service Quality and Customer Satisfaction: An empirical investigation in Indian mobile telecommunication service.”, Bentley University Sanjith Kumar Roy, Bentley University Shirshendu Ganguly, ICFAI University, India. 
Glaveli N., Petridou E., (2006), "Bank service quality: evidence from five Balkan countries", Journal of Service Theory and Practice 16(4):380-394

DOI:

10.1108/09604520610675711

Gowan M., Seymour J., Ibarreche S., (2001), "Service quality in a public agency: same expectations but different perceptions by employees, managers, and customers" Journal of Quality Management, 6: 275-291. http//:www.ceb.lk

Johnson Kuby, (2007). Elementary Statistics, Brooks/Cole20, USA ISBN-13: 978-0-538-73350-2

Khan M.M., Fasih M., (2014), "Impact of Service Quality on Customer Satisfaction and Customer Loyalty: Evidence from Banking". Pakistan Journal of Commerce and Social Sciences, Vol. 8 (2), PP:331- 354.

Parasuraman, A., Zeithaml, V. A. \& Berry, L. L. (1988). SERVQUAL: A Multi-Item Scale for Measuring Consumer Perceptions of Service Quality. Journal of Retailing, 64 (Spring), 21-40.
Riadh Ladhari A., (2009), "Service quality, emotional satisfaction, and behavioural intentions: A study in the hotel industry" Managing Service Quality: An International Journal, Vol. 19 No. 3, pp. 308331. https://doi.org/10.1108/09604 520910955320

Zeithaml, V.A., Bitner, M.J., (1996) Services Marketing. McGrawHill, New York.

Zeithmal V.A., (1988), Consumer Perceptions of Price, Quality and Value, Journal of Marketing, Volume: 52 (3): 2-22, https://doi.org/10.1177/00222429880 5200302

Zeithmal V.A., Bitner M.J., Gremier D.D., Pandit A., (2013), Services Marketing, Integrating customer focus across the firm, 6th Ed, New Delhi. 


\section{Appendix 1}

Table 2. Descriptive Statistics

\begin{tabular}{|c|c|c|c|c|}
\hline Code & Factor & Statement & Mean & $\begin{array}{c}\text { Std. } \\
\text { Deviation } \\
\end{array}$ \\
\hline $\mathrm{T} 1$ & \multirow{5}{*}{ Tangibility } & $\begin{array}{l}\text { Do you think that electricity board should have } \\
\text { modern-looking equipment }\end{array}$ & 4.28 & 1.0481 \\
\hline $\mathrm{T} 2$ & & $\begin{array}{l}\text { Do you think that electricity board's physical } \\
\text { facilities should visually appealing }\end{array}$ & 4.3 & 1.0199 \\
\hline T3 & & $\begin{array}{l}\text { Do you think that electricity board's employees } \\
\text { should neat appearing }\end{array}$ & 4.41 & 0.7941 \\
\hline $\mathrm{T} 4$ & & $\begin{array}{l}\text { Do you think that the materials associated with the } \\
\text { service (forms, electricity bill etc.) should visually } \\
\text { appealing }\end{array}$ & 4.21 & 0.7937 \\
\hline $\mathrm{T} 5$ & & $\begin{array}{l}\text { Do you think that Electricity board services should } \\
\text { performed within the promised time }\end{array}$ & 4.14 & 0.9794 \\
\hline E1 & \multirow{5}{*}{ Empathy } & $\begin{array}{l}\text { Do you think that electricity board should provide } \\
\text { you an individual attention }\end{array}$ & 4.33 & 1.0061 \\
\hline E2 & & $\begin{array}{l}\text { Do you think that electricity board should have } \\
\text { convenience operating hours to your needs }\end{array}$ & 4.1 & 1.0251 \\
\hline E3 & & $\begin{array}{l}\text { Do you think that electricity board should have } \\
\text { employees who give your personal attention }\end{array}$ & 4.2 & 0.9386 \\
\hline E4 & & $\begin{array}{l}\text { Do you think that electricity board should } \\
\text { considers your wishes and needs }\end{array}$ & 4.08 & 1.1613 \\
\hline E5 & & $\begin{array}{l}\text { Do you think that electricity board employees } \\
\text { should understanding of your specific needs }\end{array}$ & 4.28 & 0.8864 \\
\hline Res1 & \multirow{4}{*}{ Responsiveness } & $\begin{array}{l}\text { Do you think that in the electricity board you } \\
\text { should not spent much time waiting in line }\end{array}$ & 4.46 & 0.777 \\
\hline Res2 & & $\begin{array}{l}\text { Do you think that electricity board employees } \\
\text { should always willing to help }\end{array}$ & 4.08 & 0.8382 \\
\hline Res3 & & $\begin{array}{l}\text { Do you think that electricity board employees } \\
\text { should quick in eliminating potential errors }\end{array}$ & 4.67 & 0.6237 \\
\hline Res4 & & $\begin{array}{l}\text { Do you think that electricity board employees } \\
\text { should quickly respond to your requests }\end{array}$ & 4.62 & 0.6132 \\
\hline $\mathrm{R} 1$ & \multirow{4}{*}{ Reliability } & $\begin{array}{l}\text { Do you think that when you have a problem, the } \\
\text { electricity board's employees should show sincere } \\
\text { interest in solving the problem }\end{array}$ & 4.71 & 0.5306 \\
\hline $\mathrm{R} 2$ & & $\begin{array}{l}\text { Do you think that electricity board should } \\
\text { correctly performs the service right the very first } \\
\text { time }\end{array}$ & 4.38 & 0.8274 \\
\hline R3 & & $\begin{array}{l}\text { Do you think that electricity board should provide } \\
\text { its service right the first time }\end{array}$ & 4.52 & 0.7244 \\
\hline $\mathrm{R} 4$ & & $\begin{array}{l}\text { Do you think that electricity board should insists } \\
\text { on error free records (calculate electricity bill) }\end{array}$ & 3.87 & 1.08182 \\
\hline A1 & \multirow[b]{2}{*}{ Assurance } & $\begin{array}{l}\text { Do you think that electricity board employees } \\
\text { should trustworthy }\end{array}$ & 3.93 & 0.96491 \\
\hline $\mathrm{A} 2$ & & $\begin{array}{l}\text { Do you think that you should feel safe in using } \\
\text { electricity power }\end{array}$ & 3.75 & 1.24135 \\
\hline
\end{tabular}




\begin{tabular}{|c|c|c|c|c|}
\hline A3 & & $\begin{array}{l}\text { Do you think that electricity board employees } \\
\text { should consistently courteous towards you }\end{array}$ & 3.93 & 0.99562 \\
\hline CT & Tangibility & $\begin{array}{l}\text { Do you think that Customer satisfaction is } \\
\text { depending on Tangibility }\end{array}$ & 4.25 & 0.8926 \\
\hline $\mathrm{CE}$ & Empathy & $\begin{array}{l}\text { Do you think that Customer satisfaction is } \\
\text { depending on Empathy }\end{array}$ & 4.39 & 0.8283 \\
\hline CRes & Responsiveness & $\begin{array}{l}\text { Do you think that Customer satisfaction is } \\
\text { depending on Responsiveness }\end{array}$ & 4.7 & 0.5256 \\
\hline CR & Reliability & $\begin{array}{l}\text { Do you think that Customer satisfaction is } \\
\text { depending on Reliability }\end{array}$ & 4.41 & 0.7938 \\
\hline CA & Assurance & $\begin{array}{l}\text { Do you think that Customer satisfaction is } \\
\text { depending on Assurance }\end{array}$ & 4.43 & 0.8487 \\
\hline
\end{tabular}




\section{Appendix 2}

Table 4. Results of Correlation Analysis

\begin{tabular}{|c|c|c|c|c|c|c|c|c|c|c|c|}
\hline & & $\mathrm{CSl}$ & & & & & & & & & \\
\hline \multirow[b]{2}{*}{$\mathrm{CS} 1$} & Pearson Conelation & 1 & & & & & & & & & \\
\hline & $\begin{array}{l}\text { Sig, (2-tziled) } \\
\mathrm{N}\end{array}$ & & $\mathrm{CS} 2$ & & & & & & & & \\
\hline \multirow[b]{3}{*}{$\operatorname{cs} 2$} & Pearson Comelation & $0.498^{4 *}$ & 1 & & & & & & & & \\
\hline & Sig, (2-tziled) & .000 & & & & & & & & & \\
\hline & $\mathrm{N}$ & 300 & 300 & $\operatorname{CS} 3$ & & & & & & & \\
\hline \multirow[b]{3}{*}{$\mathrm{CS} 3$} & Pearson Conrelation & $.194 \%$ & $.341^{* *}$ & 1 & & & & & & & \\
\hline & Sig (2-tziled) & .001 & .000 & & & & & & & & \\
\hline & $\mathrm{N}$ & 300 & 300 & 300 & $\operatorname{cs} 4$ & & & & & & \\
\hline \multirow[b]{3}{*}{$\operatorname{cs} 4$} & Pearson Comelation & $.451^{4 *}$ & $.808^{444}$ & $.458^{44}$ & 1 & & & & & & \\
\hline & Sig, (2-tziled) & .000 & .000 & .000 & & & & & & & \\
\hline & $\mathrm{N}$ & 300 & 300 & 300 & 300 & $\operatorname{cs} 5$ & & & & & \\
\hline \multirow[b]{3}{*}{$\operatorname{Cs} 5$} & Pearson Conelation & .088 & .059 & $.150^{44}$ & .099 & 1 & & & & & \\
\hline & Sig, (2-tziled) & .127 & .304 & .009 & .087 & & & & & & \\
\hline & $\mathrm{N}$ & 300 & 300 & 300 & 300 & 300 & I All & & & & \\
\hline \multirow[b]{3}{*}{ Inatll. } & Pearson Comelation & $.314^{4 *}$ & $.474^{4 *}$ & $.190^{44}$ & $516^{4 *}$ & $327^{44}$ & 1 & & & & \\
\hline & Sig, (2-tziled) & .000 & .000 & .001 & .000 & .000 & & & & & \\
\hline & $\mathrm{N}$ & 300 & 300 & 300 & 300 & 300 & 300 & EAdlt & & & \\
\hline \multirow[b]{3}{*}{ Evall. } & Pearson Conrelation & $.300^{4 *}$ & .3904 & .097 & $324^{* 4}$ & $.173^{4 *}$ & $.668^{44}$ & 1 & & & \\
\hline & Sig. (2-triled) & .000 & .000 & .093 & .000 & .003 & .000 & & & & \\
\hline & $\mathrm{N}$ & 300 & 300 & 300 & 300 & 300 & 300 & 300 & Bes All & & \\
\hline \multirow[b]{3}{*}{ Bes All } & Pearson Comelation & .2904 & $.190^{4 *}$ & .302 & $311^{* 4}$ & .07944 & $.436^{4 *}$ & $.5577^{44}$ & 1 & & \\
\hline & Sig (2-tziled) & .000 & .000 & .000 & .000 & .170 & .000 & .000 & & & \\
\hline & $\mathrm{N}$ & 300 & 300 & 300 & 300 & 300 & 300 & 300 & 300 & Belidall & \\
\hline \multirow[b]{3}{*}{ Beliantld } & Pearson Comelation & $.211^{* *}$ & $.288^{44}$ & $221^{4 *}$ & $256^{4 *}$ & -.044 & $360^{4 *}$ & $389 * 4$ & $.699 *$ & 1 & \\
\hline & Sig. (2-triled) & .000 & .000 & .000 & .000 & .445 & .000 & .000 & .000 & & \\
\hline & $\mathrm{N}$ & 300 & 300 & 300 & 300 & 300 & 300 & 300 & 300 & 300 & Axp All \\
\hline \multirow[b]{3}{*}{ Assgn All } & Pearson Comelation & $.308^{4 *}$ & $.486^{4 *}$ & $286^{4 *}$ & $.426^{4 *}$ & $.205^{*}$ & $.622 \%$ & $.6533^{44}$ & .6374 & $504^{4}$ & 1 \\
\hline & Sig, (2-triled) & .000 & .000 & .000 & .000 & .000 & .000 & .000 & .000 & .000 & \\
\hline & $\mathrm{N}$ & 300 & 300 & 300 & 300 & 300 & 300 & 300 & 300 & 300 & 300 \\
\hline
\end{tabular}

